\title{
The Effect of Process Writing Practice on the Writing Quality of Form One Students: A Case Study
}

\author{
Majid Pour-Mohammadi, PhD Candidate \\ Islamic Azad University, Rasht, Iran
}

Tel: 60-17-605-4350Ｅ-mail: majid.pourmohammadi@gmail.com

Dr. Mohamad Jafre Zainol Abidin

School of Educational Studies, University of Science Malaysia, 11800 Penang, Malaysia

E-mail: Jafre@usm.my

Cheong Lai Fong, MA

School of Educational Studies, University of Science Malaysia, 11800 Penang, Malaysia

\author{
Received: August 20, $2011 \quad$ Accepted: September 9, $2011 \quad$ Published: March 1, 2012 \\ doi:10.5539/ass.v8n3p88 \\ URL: http://dx.doi.org/10.5539/ass.v8n3p88
}

The research has partly been financed by the Fellowship Scheme of University of Science Malaysia.

\begin{abstract}
Teachers who teach English as a second language are committed to develop an understanding and improvement of second language writing as learning to write in the second language is a complicated process. Despite the numerous research on second language writing, the phenomenon of writing is constantly under investigation as teachers want to share the findings of each study which provides knowledge that resonates with their teaching experience. This case study is a report about the effect of process writing practice on the writing quality of three Form one students. This study uses observation, interview, students' drafts, and writing and examination scores as sources for data collection. The analyses show some effects on their writing pace and writing quality. The findings also reveal that students are able to attempt writing despite the difficulty of the given writing task.
\end{abstract}

Keywords: Process writing practice, Second language learner, Writing quality

\section{Introduction}

Writing in language classrooms is inevitably an important skill and therefore, becomes the focus of instruction. According to Hyland (2003), writing has been identified as one of the essential process skills because our world has been driven by text and numerical data more than ever. The status of writing has been further strengthened due to the expansion of knowledge and studies of genre and writing processes. This creates a great interest in the approaches of second language writing instruction that incorporate current theory and research findings.

Students perceive productive skills namely speaking and writing as more difficult skills than listening and reading (Berman \& Cheng, 2010). In the context of Malaysia, writing is the skill that most students are least proficient in (Nesamalar, Saratha \& Teh, 2001). The interference of the first language will affect the way sentences are structured and ideas are presented. A study carried out on the essays of Malaysian secondary students showed that most errors made in written work were mainly tenses, subject verb agreement, prepositions and the mechanics of writing (Darus \& Ching, 2009).

Although research and theories on how to teach students to write using composing strategies are provided in literature, teachers need time to learn how to explain, model, and scaffold the strategies to students in classrooms (Pressley et al., 2007). Besides, some composing strategies and writing models need to be adapted accordingly to meet the needs of students of different proficiency levels, learning motivation and social background. 


\subsection{Statement of the Problem}

Despite the explosive growing field of second language writing, teaching writing to ESL learners remains a challenge in Malaysia. Research shows that students are less competent in using the language due to high incidence of linguistic errors in their essays (Darus \& Ching, 2009; Darus \& Subramaniam, 2009; Jalaluddin et al., 2008).

The Form one English syllabus specifies the application of process writing skills in presenting information (Ministry of Education, 2003). Based on reports of writing instruction in Malaysian classrooms made by Heng and Chan (1996), Mahaletchumy (1994), and Bhajan (1995), the process writing practice is yet to be implemented by teachers during writing lessons. According to Chow (2007), the reason why traditional writing instruction remains dominant is the teachers' attitude. Teachers who are taught and trained in the product writing practices naturally conduct writing lessons according to the way they learn writing in school, teachers training college or university. Their pedagogical belief strongly influences their teaching practices. Moreover, the emphasis of linguistic accuracy and writing mechanics in the assessment of students' writing causes concern among teachers to instruct students to produce work that shows good use of language with error free structures. Although process writing instruction was introduced in the late 1980s, writing in the Malaysian classrooms remains structural and teacher-centred (Chow, 2007).

This research investigates the writing process of Form one students in classroom and how it affects their writing quality in aspects of ideas, organisation and sentence fluency. It also provides a description of the aspects of writing quality of the Form one students who use process writing practice to perform their writing tasks in classroom.

\subsection{Research Questions}

The study is guided by the following research questions:

How does process writing practice affect students on their writing strategies and pace of writing?

What are the aspects of writing quality of the Form one students who use process writing practice to perform writing tasks in classroom?

What are the total writing assessment scores of these students?

\section{Literature Review}

Writing research is "not a unified, coherent one" as the theoretical frameworks which define and outline the field "adopt different methodological, epistemological and ontological stance" (Beard et al., 2009, p. 17). The theoretical frameworks that characterize writing research are: psychological, sociocultural and linguistic. The psychological theoretical framework conceptualizes writing as a cognitive process. Alamargot and Chanquoy (2001) believe in order to write, one "needs a coordinated implementation of a large set of mental activities." In the 1970s and 80s, scholars applied theories of cognitive psychology to the study of writing processes. Chomsky advocated that to study language was to investigate the structure of the mind and hence, the cognitive process revolutionized linguistics (Nystrand, 2006).

Before the 1970s, writing instruction focused on prescriptive text features of model texts. Rules of grammar governed the character of instructional discourse. This traditional concept of writing and writing instruction received much critique which eventually caused language and education specialists to propose instruction rooted studies about individual learning and processes of the mind. These empirical studies which are rooted on cognitive revolution began with Emig (1971) who investigated writing as a cognitive composing process. Then, Hayes and Flower (1980) developed a cognitive model of writing processes, identifying the components and organization of long term memory, planning, reviewing and translating thought into text. Other cognitive research includes Scardamalia and Bereiter's (1987) study of writing processes (Nystrand, 2006).

Although second language writing instruction comes from theories and principles of first language research, ESL teachers need to address the significant differences between first language writers and second language writers as noted by Silva (1993) in his review of studies comparing research into first and second language writing. Second language writers have a different linguistic base than native English speakers who can intuitively handle the language. Second language writers struggle with the language due to their inadequate grasp of grammar or vocabulary or both. Research has shown that work produced by second language writers are shorter, less cohesive and have more errors (Hyland, 2003). 


\subsection{Teaching Writing}

Writing involves composing, to tell or retell pieces of information in the form of narratives or description (Myles, 2002). Writing is not merely copying some words or isolated sentences to structure a set of coherently and grammatically-sound sentences. It takes time to develop writing skills and these skills must be learned and put into practice. To develop writing expertise, a writer needs to realize, control and manage his mental activities and the constraints that limit him from writing effectively. Therefore, a lot of practice, training and techniques are needed to produce a quality piece of writing.

According to Alamargot and Chanquoy (2001), to create a written text, it requires at least the use of four types of knowledge: domain knowledge (conceptual domain expressed in text), linguistic knowledge (grammatical rules and lexical items that compose the text), pragmatic knowledge (that allows the writer to adapt for the reader the content and linguistic form of the text) and procedural knowledge (the use of the three preceding types of knowledge and strategically processing them). A general writing process fulfills the processing of each of these types of knowledge. The domain knowledge is transformed into a strict linear linguistic product which is complied with a specific communicative goal. As the cognitive system has a limited processing capacity, the communicative goal is subdivided into sub-goals and each sub-goal is realized by specific processes which are controlled by procedural knowledge.

\subsection{Process Writing Practice}

In the 1970s, an interest in the writing process emerged. First language writing teachers and researchers believed that the writing process is what writers actually do as they write. Thus, process writing approaches were implemented in classroom, characterized by journals, invention, students' choice of topics and attention to content before form (Raimes, 1991).

Scardamalia and Bereiter (1987) conducted the first study of written composition among adolescents. To enable students to produce more fully elaborated writing, teachers need to help them become better knowledge tellers. It is more than teaching procedures or motives but helping students develop a cognitive structure within which the process of composing produces reconstruction of knowledge. Novice writers depend on having knowledge already enabled either in memory or through teacher-directed writing activities for written presentations (Scardamalia \& Bereiter, 1987). Written composition which initially takes the form of the straight forward transcription of knowledge without any reorganization of the text's conceptual content or linguistic form may result in a good quality production, as in the case of narratives. Fayol explains that this is due to the sequence of events that generally corresponds to the order in which they are formulated (Alamargot \& Fayol, 2009).

The knowledge telling strategy is elaborated in a writing model. The model illustrates how text generation occurs; First, the writer defines the task at the mental representation of assignment stage. The second component includes content knowledge which allows the elaboration of text content and discourse knowledge which is concerned with linguistic knowledge and knowledge about the text type. The third component which has seven stages is the writing process labeled knowledge telling process. Here, topic and text type identifiers are located. Topic identifiers serve as cues for memory search and they automatically connect to relevant concepts. They guide the functioning of the operation of construct memory probe which helps to retrieve content knowledge in the fourth operation - retrieve content from memory using probes. There retrieved contents are then tested for appropriateness on the test topic and nature. If the knowledge is inappropriate, the memory probes are again elaborated by the operations of locate topics identifiers and locate genre identifiers. If the retrieved knowledge is coherent with the text topic and nature, they can advance to the write operation. At the end of the writing stage, update mental representation of text allows the writer to identify what has been written and what has to be written (Scardemalia \& Bereiter, 1987; Alamargot \& Chanquoy, 2001).

Applied into second language classroom context, the teacher's role in process writing practice is to help students develop strategies, getting them started by generating ideas and information, encouraging multiple drafting, revising drafts (adding, deleting, modifying and rearranging ideas) and editing. The writer is the centre of attention (Silva, 1993). Process writing tends to encourage the implementation of open-ended tasks with the emphasis on personal expression in more extended stretches of written discourse. In process writing, discovery and communication of meaning are vital, giving priority to the development of processing skills and general discourse knowledge rather than the acquisition of specific language knowledge (Bruton, 2005).

Findings of studies conducted on first language writers revealed that process writing evidenced improvement in students' writing. A summary report of National Assessment of Educational Progress stated that "teaching the cluster of writing techniques known collectively as writing process is associated with higher average writing proficiency among students" (Goldstein \& Carr, 1996, p. 1). It was reported that overall students who received 
the process method had greater improvement in their expository writing, but not in their creative writing, than did students in the control group (Pritchard \& Honeycutt, 2006).

As this research examines the effects of process writing practice which focus on the ability to establish communication and development of general discourse knowledge rather than specific language knowledge, the quality of the students' writing is limited to three of the traits in the six-trait assessment model. The traits are ideas, organization and sentence fluency.

\section{Methodology}

\subsection{Participants}

The participants of this study were three Form one students in a secondary school in the southwest district of the Penang Island, Malaysia. The selection of the participants for this case study was purposive in nature and they were selected based on their willingness to participate, the researchers' observation of these students during lessons and feedback from their English teacher. They were 13-year-old students who had just finished their primary school. These participants, with language proficiency level of high, middle and low, secured a B, C and D for their English in the Primary School Evaluation Test (PSET) and the school's midyear examination (SME). They adopted the process writing approach as a writing practice in the English classroom for a period of eight weeks. The seventy-minute lessons used for their process writing practice were twice a week.

\subsection{Data Collection Sources}

The sources of evidence for this case study were nonparticipant observation, semi structured interviews, the English test scores of the participants in the PSET examination and the school midyear examination, and their written works.

\subsubsection{Observation}

The nonparticipant observation adopted in this study enabled the researchers to focus on the three participants to describe what actually happened when the participants used process writing to carry out their writing tasks in classroom. A protocol was used to guide the observation and structure the recording information during the writing sessions in classroom. The protocol for observation was pilot tested on one student before it was used in actual observation. Information recorded during the observation was coded and compiled.

The observation protocol comprised five components: setting, planning stage, composing and drafting stage, responding and revising stage, and editing stage. The setting refers to the time, duration of observation, and seating position of the participants. The planning stage began when the participants were given their writing task. At this stage, they were observed for the time they used to complete their outline and what they did as they completed their outline. When the participants began writing their first drafts, they were observed for using their outlines and the time used to complete their first drafts was recorded. During the responding and revising stage, the researchers took note of the responses given by peers and teacher, and what the participants did with their first drafts. The time used to write the second drafts was recorded again. Editing, the last stage, was done before submission. At this stage, the participants were observed whether they read back what they had written and made corrections to their writing.

\subsubsection{Interview}

The interview conducted to elicit responses from the participants was semi structured and formal. A specific set of questions used to guide the interview sessions consisted of three categories: profile of participant, dimensions of process writing during writing practice, and the effects of process writing on the participants. Questions were mainly closed questions because the participants found difficulties responding to open ended questions that require them to explain and give reasons. Hence, the researchers had to structure questions that provide participants with options. The interviews were carried out after all the writing tasks were completed. Duration for each interview was about ten to fifteen minutes and each session was videotaped.

\subsubsection{Participants' Test Scores}

The English test scores are the tests scores of the PSET and SME examinations. They represent the participants' proficiency levels in the language. The English PSET examination consists of two papers. Paper one is composed of 40 multiple-choice questions that test students' ability on vocabulary, grammar, punctuation, spelling and reading. Paper two consists of three sections. Section one requires students to write five sentences based on a given picture. Section two tests the ability of students to complete a table with details of three items and to write reasons of choosing one of the items in a paragraph. Section three tests the students' ability to write a story based on given pictures and words. The participants sat for the papers in 2009 and their scores were recorded by their English teachers at the beginning of the school year in 2010. 
The English school midyear examination, administered in June 2010, is based on the Lower Secondary Assessment examination format which consists of two papers. Paper one comprises 40 multiple choice questions that test students' ability on knowledge of grammar, vocabulary, phrases and idioms, and their ability to interpret information based on graphical stimuli. As students are exposed to the literature component in Form one, they are also tested on their knowledge of the literature texts they have read. In paper two, students are to write a long essay of not less than 120 words, a summary and a response of the literature text they have read.

\subsubsection{Drafts of Participants}

In eight weeks, five writing tasks were given to the participants. The first two tasks were completed in a week's time but the remaining tasks needed an additional week for each. The tasks were based on the topic, My Brother's Keeper, from the English Form one text book. The first two tasks required the participants to write responses as to create the opportunity for them to respond to helping others and develop the idea of helping those in need. The remaining three tasks were narrative writing. The third task involved writing a story about how a prince helps the poor in his country. The fourth task required the participants to write a story based on pictures from the text book. Words were provided in the rubric. The fifth task was to write a story based on a given situation. The situation was about saving an injured cat by the road. For each of these tasks, the participants were given two weeks to accomplish the task. During the two weeks, they planned, wrote their first drafts, received respond from their peers and teacher and revised their drafts, wrote their second drafts, edited and submitted their essays.

The work submitted was assessed using an analytical scoring guide adapted from a writing assessment model (Spandel, 2001). The essays were assessed on each aspect of writing quality, ideas, organisation and sentence fluency. The essays were assessed on a five-point scale; 5 represents strong, 3 developing and 1 beginning performance levels. Score of 4 represents transitional levels from 3 to 5 and score of 2 for transitional levels from 1 to 3, respectively. The levels of performance for each writing trait are defined in Appendix.

\subsection{Validity and Reliability}

To establish the trustworthiness and understanding of the research findings, strategies adapted from Guba's (1981) classic discussion in Criteria for Assessing the Trustworthiness of Naturalistic Inquiries were used. Besides, peer debriefing and practiced triangulation was adopted as means to ensure the trustworthiness and understanding of the findings. Observation field notes were checked with the participants' English teacher who was present during the observation sessions. The essays written by the participants were rated by one of the researchers and another English teacher who was more than twenty years of teaching experience. Differences of scores were summed and averaged. Descriptive data were collected as accurate as possible and statements from participants were quoted. Analyses and interpretations were checked to establish referential adequacy.

\subsection{Data Analysis Procedure}

Data made during the observation in classroom were categorized and coded, grouping them into different dimensions of the writing process to enable findings to be analysed and provide answers to the research questions in this study. Features during observation were identified and coded. Time used by the participants to complete their drafts was also recorded. After the observation, interviews were conducted with the participants to obtain more information about their experience of the process writing practice and confirm the data collected during the observation. Transcriptions of the interviews were also coded and structured according to the dimensions of the writing process. After analysing data from the observation and the interview, drafts of the participants were read and rated analytically. Then, pattern matching by comparing empirically based patterns with predicted ones was used to describe the general characteristics and relations of phenomenon in question.

\section{Results}

This section reports the findings, providing an analysis of the data which were collected and triangulated.

\subsection{Writing Strategies}

From the observation and interview, the three participants adopted five strategies to generate ideas. Of the five strategies mentioned in table 1 , consulting the teacher was necessary for all participants to help generate ideas for writing their outlines. They believed that clear explanations made by the teacher before writing enabled them to do better and easier writing. The other strategies, except translating, were favored by two out of three participants. Only student 3 did translation from Malay into English before writing. This is associated with his lower second language proficiency as a study on the use of first language in developing ideas in second language writing by Stapa \& Majid (2009) revealed that students with lower level of English proficiency can generate better ideas for second language writing with the use of first language. 


\subsection{Pace of Writing}

The ability of the participants to generate ideas within a time frame at the pre writing varies greatly between student 3 and the other two students. Student 1 appears to be able to produce 135 words in 5.14 minutes, which means 26.26 of words per minute. This is in task 4. For task 5, she can write 99 words in 3.29 minutes, which means 30.09 words per minute. Student 2 can write 145 words in 5.50 minutes during the task 4 and 81 words in 4.22 minutes during task 5 . It shows she can compose 26.36 words per minute for task 4 and 19.19 words per minute for task 5 . As for student 3 , for task 4 , he can write 26 words in 5.20 minutes which is 5 words per minute and 14 words in 3.22 minutes, which is 4.35 words per minute. The difference between student 3 and the other two students is probably caused by the strategy used to generate ideas. Student 3 needs to write first in Malay and translate later into English in writing the outline.

Time used to complete their first drafts became shorter. To find out the ability of the participants to write in one minute, the number of words written by each participant in each draft was divided with the time used (in minutes) to complete the draft. Participants appeared to write more although they finished their task faster. There is a difference in the participants' ability to write their first drafts in the five tasks. However, for student 1 , the quantity of her drafts in task four and five decreased. She started to write shorter script. Student 2 could write more words in shorter time. Student 3 showed efficiency in developing ideas as he could write faster.

\subsection{Writing Quality}

\subsubsection{Ideas}

Scripts submitted by student 1 after the process writing practice had rich details and well expressed thoughts. Although her scripts for the second and fifth task were short, she was still able to focus on what she was writing and presented her ideas relevant to the outline she had made at the pre writing stage. However, she needed to carefully select her examples and include details that were more significant to enhance her writing. She followed the outline closely and even found the outline very useful when she was interviewed after completing the five writing tasks. The second draft of student 1 showed no significant difference in her ideas development. Instead, she concentrated on her organization and sentence fluency. Although her teacher had responded to her first draft for the fifth task concerning her ideas development, she hardly incorporated the written and verbal responses given to her as she wrote her second draft. It was at the editing stage that she added a short sentence to the ending of her story. When she was asked during the interview, she said her friend commented about her essay. "They say long essay: if longer, more mistakes."

Drafts of student 2 were mainly presentations of general ideas with few significant details. The ideas in her first draft and second draft for four of the writing tasks showed no elements that appear important. During the interview, she expressed her feelings about revising and redrafting. She said, "sometimes tiring". She believed that writing one draft was good enough. When she was asked whether responses given by friends and teacher at the revising stage were useful, she agreed. Although she acknowledged the importance of the responses, changes made based on the responses at the revising and second drafting stages may not be apparent in the second drafting. This was because writing the first draft was laborious for this participant.

Student 3 wrote short scripts. However, he completed the task given. It was not impossible to understand the main theme or the story. What was seriously lacking in his drafts was close up details and clarification. At the pre writing stage, he made attempt to outline his ideas using the translation strategy and the effort got him started writing. He did not initiate peer conference to get responses from friends unless instructions were made by the teacher. His reason given in the interview was, "Response from teacher is good, friends' response is not good." He agreed that he did not understand what friends were talking about. When he was asked which response given by teacher was good for him, he said, "I do so fast." That boosted his confidence. He agreed that he could ask the teacher for ideas to improve his essay. As he incorporated the response given by the teacher and approached his teacher for ideas and clarification, he made progress in his second draft. This was apparent when he was doing his fourth writing task. However, when he was revising the second draft for the fifth task, he was seen copying sentences from the first draft. Hence, the second draft showed no improvement.

\subsubsection{Organization}

The final drafts of the three participants showed good organization. Transitions were used and the participants were aware of sequencing. Essays of student 2 and 3 were more formulaic and pacing was sometimes awkward. For instance, student 3 wrote the following in his first draft for task 4:

"Mrs Rama and her friends made a twelve blankets for the children. After that, all three families go to children's home. On the weekend they gave the blankets to the children and the children was very happy." 
However, after revising his first draft, he wrote:

"After that, Mrs Rama and friends started and made the blankets. As the result, they manage to make twelve blankets by using the collected old clothes. On the weekend, all the three families went to the children's home together. They gave the beautiful blankets to the children. The children felt very touched and happy."

At the pre writing stage, the outline they made provided them the internal structure to piece together their ideas. The participants were aware of planning during the writing process and in fact as student 3 said, "it is important". As they reread and incorporated the responses from their teacher and friends at the revising stage, they made changes to their writing which were apparent to their organization and pacing in their last drafts. Student 1 remarked that she liked to rewrite because "essay can be better than the first one". These writing process skills developed not only their ability to organize their ideas but also to enable students to create writing that was coherent and cohesive.

\subsubsection{Sentence Fluency}

The last drafts of the participants achieved fairly easy reading. However, structures were more mechanical, making reading less pleasant. Occasionally, student 3 had unusual constructions in his script that stumble the reader. For the fifth task, there was something written which took a while to understand what he was writing. Nevertheless, almost all the sentences could be read and understood for meaning. What hampered the flow and rhythm was the presence of linguistic errors. This also included student 1 although her language proficiency level was better than the other two participants.

Although the editing stage occurred in the writing process of these participants, they would read through their scripts very quickly. It was done immediately after they had finished writing their second draft. The purpose of reading for these participants at this stage was merely to check for errors and make corrections. However, the scripts that were handed in did not portray that these participants were as concerned with accuracy as expected. It seemed the whole process of writing was exhausting that all these participants wanted was to get the task done and submit for marking. The last drafts for task 5 were hardly different from the first draft.

\subsection{Total Writing Assessment Scores}

The participants in this study had different levels of language proficiency which were determined by the PSET and SME examinations scores they obtained. The scores in table 2 reveal the participants' language proficiency. The scores for both examinations are derived from adding the scores of sections that test the knowledge of grammar and vocabulary, reading and writing skills. The SME is slightly different as there are additional components of summary and literature. These scores are not able to reveal the writing ability of the participants specifically as they are the total scores of all the sections that test different language abilities.

Unlike the findings in a study conducted by Raimes (1985) on unskilled ESL students, the language proficiency test scores of the participants did correspond with their analytical scores on their first drafts. However, student 3 , whose language proficiency test scores were lower than the other two participants, showed improvement in his final draft (as compared to the first draft) in all aspects: ideas, organization and sentence fluency.

The total scores derived from adding the sub scores of each aspect of writing which are ideas, organization and sentence fluency for each participant are slightly different between the first and second drafts (table 2). Some scores are not obtained because the participant was not present at the revising stage. The total scores for different tasks can differ. However, it is interesting to note that when the total score for the first draft is low, the total score for the second draft follows. This is because the participants make very small changes to their writing despite the responses given by the teacher and friends at the revising stage.

The marginal changes the participants made in their last drafts could account for the same scores between the first and last drafts. Even when changes were made to their last drafts, they did deeply affect the three aspects of ideas, organization and sentence fluency and hence, were not able to bring the scores higher than the scores obtained for the first drafts.

The total scores for each participant over the five writing tasks indicate that under different contexts, students may perform differently although they use the same writing process to produce their texts. The last draft total scores for task 4 are high for each participant but the scores do not maintain at task 5. Student 1 who scored a total of 13 out of 15 managed only a score of 10 for task 5 . Student 2 who had a score of 9 got a 7 for her task 5 and student 3 whose score was a 9 for task 4 got a 6 for task 5 . The response from the participants about difficult task was not that they did not know how to write. Student 1 agreed that if the task was difficult, she still had ideas on how to write. Student 2 thought that a task with a topic which she knew about would make her write better. Student 3 said if the task was difficult, he would go slower. 


\section{Discussion}

The findings reveal the effects of process writing practice on the participants' writing which have important implications to writing instructions in classroom. In finding answers to the issue of this study, the practice of process writing among the participants entails not only writing quality but also the strategies and pace in producing a text.

\subsection{Writing Strategies}

Writing strategies at the pre writing stage are crucial to get these budding writers started with the task. More often than not, we see students who stare at the paper and read the task again and again only to struggle with their first sentence. Writing does not come naturally and easily for some students as writing essays, according to Hillocks (2006), involves the most complex thinking.

It appears that the participants value the moment of discussion with their teacher as they brainstorm for ideas in the writing process. The teacher asks WH questions to probe these students helping them to retrieve content from memory, provides input by sharing new experiences and knowledge about the writing topic, gives specific instructions on how to write an outline to arrange ideas into paragraphs and responds to illuminate uncertainties to help students make meaning of the task. Learners at this stage depend on their teacher for guidance.

According to Gosden (1996), translation from first language into second language is common. However, students who have higher second language ability do not consider translation. It is possible that they may have thought in their first language and write in the second language as the influence of first language on second language writing is evident in the findings of this study as well as in other studies (Leki et al., 2006). The use of translation, as was adopted by student 3 , is found to slow down the initial stage of writing, that is the pre writing stage, but the ability to write faster improves when this student proceeds to the composing stage. Hence, strategies at the pre writing stage play a significant role in assisting these second language writers to generate and organize their ideas into frameworks that enhance their writing quality in their drafts. A good start will put these writers at the right track of accomplishing the complicated process of writing.

\subsection{The Pace of Writing}

Writing at a faster pace is achieved at the composing stage once the outline is made. With close reference to the outline, participants began to write at ease and could complete their tasks faster over the eight weeks in which process writing practice was used in classroom. As participants were able to finish their tasks faster, their scripts were checked to find out the total number of words written per script. It is discovered that the total number of words varies for different tasks. Therefore, the number of words written in each script was divided with the minutes used to complete the script. The results showed that participants were able to use time efficiently. This is crucial as they are required to write within a given time limit during their examination.

\subsection{Writing Quality}

It is necessary to look into the quality of their writing although participants were able to write more words in shorter time. They might be able to write faster but does the practice of process writing affect the quality of their writing?

The quality of the ideas developed and presented by the participants in the first drafts varied according to their language proficiency. The first draft of the more proficient participant appeared to have more details than the participant who was less proficient in the language. However, as process writing involves redrafting, it is possible for participants to improve their writing with responses and revision, regardless of their language proficiency. Interestingly, more proficient students may not necessarily make drastic improvement in their second draft. Even if improvement is evident, it does not mean that students can instantly and consistently write essays that are clear and enhanced with significant details to capture the reader's interest.

As for organization, the outline at the pre writing stage is the framework for participants to put their ideas in order. Inserting transitions and understanding the sequence of events take these participants a step further into intensifying the internal structure of the essay. This provides a kind of a template for students to place their ideas as development occurs without messing up the whole arrangement. The practice of process writing itself enables students to manage their ideas in an organized fashion. As they are highly aware of planning, they are creating a "conceptual map" (Shaughnessy, 1977) or "mental blueprint" (Zamel, 1983). This will help them as they make decisions concerning form and organization when they undertake any writing tasks.

Sentence fluency can be achieved but at a moderate level. As noted earlier, process writing limits the lack of input in writing and has virtually no consideration of language input. This makes responding to actual second 
language writing difficult. Basic knowledge on syntax will enable students to establish communication through writing but to have sentence fluency, it is necessary for explicit grammatical knowledge instruction. This knowledge on grammar is best taught at the point of need and such knowledge opens up choices to writers in their acts of composition (Locke, 2009). The challenge here is how are teachers to teach this knowledge at the point of need for an individual in the Malaysian context when a class can consist of thirty to forty students or even more. How is instruction carried out when there are notable individual differences and linguistic abilities? This is what makes teaching writing that focuses on process writing a challenge.

\section{Conclusion}

Overall, the practice of process writing in classroom for the Form one students has affected the students in terms of their pre writing strategies which make the whole writing process manageable. The practice leads the students to the necessary steps to approach a writing task and this enables them to compose their drafts fast. It can also actualize the complicated plan of writing, putting the students through a journey of constructing their ideas from what is in their minds to writing and communicating these ideas to their readers. Hence, the aspects of ideas, organization and sentence fluency are crucial traits in assessing the product of the writing process.

The practice of writing, as indicated in this study, has revealed an improvement in their writing quality given the scores of their first and last drafts. Undeniably, language competence still plays a significant role in second language writing and this remains a dilemma for teachers teaching writing. Effective and strategic interventions of language are necessary to enhance the writing quality of second language writers, despite the emphasis of message over medium in using process writing practice.

\section{References}

Alamargot, D. \& Chanquoy, L. (2001). Through the models of writing. Dordrecht: Kluwer Academic Publishers. http://dx.doi.org/10.1007/978-94-010-0804-4

Alamargot, D. \& Fayol, M. (2009). Modelling the development of written composition. In R. Beard, J. Riley, D. Myhill \& M. Nystrand (Eds.), Sage Handbook of Writing Development. London: Sage Publications Ltd.

Beard, R., Riley, J., Myhill, D. \& Nystrand, M. (2009). Sage handbook of writing development. London: Sage Publications Ltd.

Berman, R. \& Cheng, L. (2010). English academic language skills: Perceived difficulties by undergraduate and graduate students, and their academic achievement. Canadian Journal of Applied Linguistics, 4(1-2), 25-40. [Online] Available: http://ojs.vre.upei.ca/index.php/cjal/article/viewArticle/169 (August 12, 2011)

Bhajan, K. (1995). Writing instruction methodology: A study of the current practices of ESL teachers. Unpublished M. Ed. Thesis, University of Malaya.

Bruton, A. (2005). Process writing and communicative task-based instruction: Many common features, but more common limitations? TESL-EJ, 9(3), 1-28.

Chow, T. (2007). The effects of the process genre approach to writing instruction on the expository essays of ESL students in a Malaysian secondary school. University of Science Malaysia. [Online] Available: http://eprints.usm.my/9356/ (July 29, 2011)

Darus, S. \& Ching, K. H. (2009). Common errors in written English essays of form one Chinese students: A case study. European Journal of Social Sciences, 10(2), 242-253.

Darus, S. \& Subramaniam, K. (2009). Error analysis of the written English essays of secondary school students in Malaysia: A case study. European Journal of Social Sciences, 8(3), 483-495.

Emig, J. (1971). The composing processes of twelfth graders. Urbana: National Council of Teachers of English.

Goldstein, A. \& Carr, P. (1996). Can students benefit from process writing? Washington D.C.: National Centre for Education Statistics (ERIC Document Reproduction Service Number ED 395 320).

Gosden, H. (1996). Verbal reports of Japanese novices' research writing practices in English. Journal of Second Language Writing, 5(2), 109-128. http://dx.doi.org/10.1016/S1060-3743(96)90021-1

Guba, E. G. (1981). Criteria for assessing the trustworthiness of naturalistic inquiries. Educational Communication and Technology Journal, 29(1), 75-91. http://dx.doi.org/10.1007/BF02766777

Hayes, J. R. \& Flower, L. S. (1980). Identifying the organization of writing processes. In L. Gregg \& E. Steinberg (Eds.), Cognitive processes in writing: An interdisciplinary approach. (pp. 3-30). New Jersey: Erlbaum. 
Heng, T. \& Chan, S. (1996). The process approach to writing: The need for an encounter. In M. David (Ed.), Innovations in approaches to the teaching and learning of English (pp. 94-98). MELTA Biennial International Conference: Kuala Lumpur.

Hillocks, G. (2006). Middle and high school composition. In P. Smagorinsky (Ed.), Research on composition: Multiple perspectives on two decades of change. NY: Teachers College Press.

Hyland, K. (2003). Second language writing. NY: Cambridge University Press. http://dx.doi.org/10.1017/CBO9780511667251

Jalaluddin, N. H., Norsimah, M. \& Kesumawati, A. (2008). The mastery of English language among lower secondary school students in Malaysia: A linguistic analysis. European Journal of Social Sciences, 7(2), 7-2. [Online] Available: http://www.teo-education.com/teophotos/albums/userpics/ejss_7_2_09.pdf (August 15, 2011)

Leki, I., Cumming, A. \& Silva, T. (2006). Second-language composition teaching and learning. In P. Smagorinsky (Ed.), Research on composition: Multiple perspectives on two decades of change. NY: Teachers College Press.

Locke, T. (2009). Grammar and writing: The international debate. In R. Beard, J. Riley, D. Myhill \& M. Nystrand (Eds.), Sage handbook of writing development. London: Sage Publications Ltd.

Mahaletchumy, N. (1994). What do ESL teachers do when they say they are teaching writing? Unpublished M. Ed. Thesis, University of Malaya.

Ministry of Education. (2003). Sukatan pelajaran kurikulum bersepadu sekolah menengah bahasa Inggeris.

Myles, J. (2002). Second language writing and research: The writing process and error analysis in student texts. TESL-EJ, 6(2), 1-20.

Nesamalar C., Saratha S. \& Teh, S. (2001). ELT methodology: Principles and practice. Selangor: Penerbit Fajar Bakti.

Nystrand, M. (2006). The social and historical context for writing research. In C. Macarthur, S. Graham \& J. Fitzgerald (Eds.), Handbook of Writing Research. NY: Guildford Press.

Pressley, M., Lindsay, M., Fingeret, L., Reffitt, K. \& Raphael-Bogaert, L. (2007). Writing instruction in engaging and effective elementary settings. In S. Graham, C. McArthur \& J. Fitzgerald (Eds.), Best practices in writing instruction. NY: Guilford Press.

Pritchard, R. \& Honeycutt, R. (2006). The process approach to writing instruction: Examining its effectiveness. In C. Macarthur, S. Graham \& J. Fitzgerald (Eds.), Handbook of writing research. NY: Guildford Press.

Raimes, A. (1991). Out of the woods: Emerging traditions in the teaching of writing. TESOL Quarterly, 25(3), 407-430. http://dx.doi.org/10.2307/3586978

Scardamalia, M. \& Bereiter, C. (1987). Knowledge telling and knowledge transforming in written composition. In S. Rosenberg (Ed.), Advances in applied psycholinguistics (pp. 142-175). Cambridge: Press Syndicate of the University of Cambridg.

Shaughnessy, M. (1977). Errors and expectations. NY: Oxford University Press.

Silva, T. (1993). Toward an understanding of the distinct nature of L2 writing: the ESL research and its implications. TESOL Quarterly, 27(4), 657-677. http://dx.doi.org/10.2307/3587400

Spandel, V. (2001). Creating writers: Through 6-trait writing assessment and instruction. NY: Longman.

Stapa, S. H. \& Majid, A. H. A. (2009). The use of first language in developing ideas in second language writing. European Journal of Social Sciences, 7(4), 41-48.

Zamel, V. (1983). The composing processes of advanced ESL students: Six case studies. TESOL Quarterly, 17(2), 165-188. http://dx.doi.org/10.2307/3586647 


\section{Appendix}

Analytical Scoring Guide for the Assessment of Drafts

\begin{tabular}{|l|l|}
\hline SCORE & $\begin{array}{l}\text { DESCRIPTION } \\
\text { IDEAS }\end{array}$ \\
\hline $\mathbf{5}$ & $\begin{array}{l}\text { The essay is clear, focused, enhanced with significant details that capture the reader's interest } \\
\text { - thoughts are deeply expressed } \\
\text { - carefully selected examples, rich details } \\
\text { - the reader is no left with important unanswered questions }\end{array}$ \\
\hline $\mathbf{3}$ & $\begin{array}{l}\text { The writer has made a solid beginning in sketching out a story line but more focus and detail will } \\
\text { breathe life into this writing } \\
\text { - easy to see where the writing is heading, even if details are needed } \\
\text { - reader grasp the big picture but elaboration is needed } \\
\text { - there may be too much information; it would help if the writer trim the deadwood }\end{array}$ \\
\hline $\mathbf{1}$ & $\begin{array}{l}\text { The writing is sketchy or loosely focused, requiring the reader to make many inferences } \\
\text { - writer needs to clarify the idea of the story } \\
\text { - writer has assembled a loose collection of ideas that do not have any real focus } \\
\text { - it is hard to identify the main theme of the story as everything seems as important as everything } \\
\text { else }\end{array}$ \\
\hline
\end{tabular}

\begin{tabular}{|l|l|}
\hline SCORE & $\begin{array}{l}\text { DESCRIPTION } \\
\text { ORGANISATION }\end{array}$ \\
\hline $\mathbf{5}$ & $\begin{array}{l}\text { The order, presentation or internal structure of the piece is compelling and moves the reader } \\
\text { purposefully through the text } \\
\text { - organisation showcases the storyline } \\
\text { - details fit perfectly in place } \\
\text { - an inviting lead and a satisfying conclusion } \\
\text { - smooth flow that the reader is not even thinking about the organisation }\end{array}$ \\
\hline $\mathbf{3}$ & $\begin{array}{l}\text { The organisation structure guides the reader through the text without undue confusion, route may } \\
\text { be circuitous but reader can still see where the write is headed } \\
\text { - sequencing seems reasonably appropriate } \\
\text { - introduction and conclusion is recognisable } \\
\text { - structure may be so dominant that it overshadows ideas }\end{array}$ \\
\hline $\mathbf{1}$ & $\begin{array}{l}\text { Ideas and details are loosely connected or even unrelated. Hard to see where the writer is headed } \\
- \text { writer skips randomly one idea to another } \\
\text { - no read lead sets up what follows } \\
\text { - no real conclusion } \\
\text { - missing or unclear transitions }\end{array}$ \\
\hline
\end{tabular}




\begin{tabular}{|l|l|}
\hline SCORE & $\begin{array}{l}\text { DESCRIPTION } \\
\text { SENTENCE FLUENCY }\end{array}$ \\
\hline $\mathbf{5}$ & $\begin{array}{l}\text { An easy flow and rhythm combined with sentence sense and clarity } \\
\text { - sentences well crafted and varied structured that invites expressive oral reading } \\
\text { - reading is pleasant and natural, never monotonous }\end{array}$ \\
\hline $\mathbf{3}$ & $\begin{array}{l}\text { The text hums with a steady beat, easy to read aloud but difficult to read with expression } \\
\text { - sentences are grammatical and fairly easy to get through } \\
\text { - graceful, natural phrasing with more mechanical structure }\end{array}$ \\
\hline $\mathbf{1}$ & $\begin{array}{l}\text { A fair interpretative oral reading of this text takes practice } \\
\text { - irregular or unusual word patterns make sentences hard to decipher } \\
\text { - ideas hooked together by numerous connectives (and...but....so...then) } \\
\text { - reader needs to pause to reread to get meaning }\end{array}$ \\
\hline
\end{tabular}

Source: Spandel (2001)

Table 1. Strategies Used by Participants to Generate Ideas

\begin{tabular}{|l|l|l|}
\hline Strategies & Definition & Example \\
\hline Reading & $\begin{array}{l}\text { Reading the assignment, } \\
\text { textbook or any other written } \\
\text { materials }\end{array}$ & $\begin{array}{l}\text { Researcher: Do you read (to get } \\
\text { ideas) } \\
\text { Yes. (student 2 and 3) }\end{array}$ \\
\hline Thinking & $\begin{array}{l}\text { Retrieving information from } \\
\text { long term memory }\end{array}$ & $\begin{array}{l}\text { Most of the time, I think (to get } \\
\text { ideas) (student 1) } \\
\text { Sometimes I spend a long time } \\
\text { thinking for ideas (student 3) }\end{array}$ \\
\hline Consulting teacher & $\begin{array}{l}\text { Talking to the English teacher; } \\
\text { asking questions; clarifying } \\
\text { meaning of words in the given } \\
\text { task }\end{array}$ & $\begin{array}{l}\text { What title should I write? } \\
\text { (student 2) } \\
\text { What means orphanage? } \\
\text { (student 3) } \\
\text { I don't know much about cat } \\
\text { (student 1) }\end{array}$ \\
\hline Asking friends & $\begin{array}{l}\text { Talking with friends about the } \\
\text { assignment }\end{array}$ & $\begin{array}{l}\text { I discuss with my friends } \\
\text { (student 1) }\end{array}$ \\
\hline Translating & $\begin{array}{l}\text { Translated the generated idea } \\
\text { from Malay into English }\end{array}$ & $\begin{array}{l}\text { Yes, I do (write first in Malay) } \\
\text { on paper because I want to } \\
\text { make it easy when I want to } \\
\text { write (my draft) (student 3) }\end{array}$ \\
\hline
\end{tabular}

Table 2. First and Last Draft Total Writing Assessment Scores

\begin{tabular}{|l|l|l|l|l|l|l|l|l|l|l|l|l|l|}
\hline Participant & & \multicolumn{10}{|l|}{ Writing tasks } & \multicolumn{10}{|l|}{ Task 3 } & \multicolumn{2}{l|}{ Task 4 } \\
\hline & PSET & SME & Task 1 & \multicolumn{2}{|l|}{ Task 2 } & \multicolumn{2}{l|}{ Task } \\
\cline { 2 - 16 } & & & FD & LD & FD & LD & FD & LD & FD & LD & FD & LD \\
\hline Student 1 & B & B & 12 & - & 10 & 10 & 11 & - & 12 & 13 & 10 & 10 \\
\hline Student 2 & C & C & 8 & 8 & 8 & 9 & 6 & - & 9 & 9 & 7 & 7 \\
\hline Student 3 & D & D & 6 & 6 & 6 & 9 & 6 & - & 6 & 9 & 6 & 6 \\
\hline
\end{tabular}

SME: School Midyear Examination

FD: First draft

PSET: Primary School Evaluation Test

LD: Last draft 